\title{
Consumers' Profiles and Behaviours towards the Intention to Use Water Filters Technology
}

\author{
Nur Khairunnisa Ahnual, Marhana Mohamed Anuar, Khatijah Omar, Hayatul Safrah Salleh
}

\begin{abstract}
Water pollution has drawn a lot of attention from all around the world. Reported studies indicated that many of the consumers prefer to use a water filter while others use boiled or bottled water for everyday consumption. This study aims to examine consumer's intention towards the use of water filters in Malaysia. A convenience sampling method was employed and the data were collected through an online survey from consumers who were aged 18 and above. The results indicated that Malaysian consumers have a high level of intention towards the use of water filters. Respondents of different marital status, ethnicity, religion, and level of education group were found to perform similar levels of intention to consume filtered water. However, there were significant differences in the intention to use a water filter by gender, age, and monthly household income.
\end{abstract}

Keywords: Demographic factors, Intention, Sustainable products, Water filter.

\section{INTRODUCTION}

The $21^{\text {st }}$ century has been a tumultuous time in terms of pollution issues. A century in which, if the predictions of pollution come true, will have the biggest impact worldwide. Pollution is more crucial than just an environmental challenge because it is a pervasive threat that impacts many aspects of human well-being and health [1]. This pollution not only impacts land creatures, as aquatic creatures are also affected by the harmful consequences. Water pollution can be defined as a contaminant that alters the water until it becomes unclean and unsafe to use for daily activities, and, more importantly harmful to consume.

All over the world, including Malaysia, water is the main source needed by the societies for life sustainability as well as for domestic activities, such as cleaning, bathing, and watering the garden. Rapid urbanization and population growth have led to the increased demand for water supply, and this rapid development has produced considerable

Revised Manuscript Received on November 11, 2019.

* Correspondence Author Development, Universiti Malaysia Terengganu, Malaysia. Email: p3366@pps.umt.edu.my

Assoc. Prof. Dr. Marhana Mohamed Anuar, Faculty of Business, Economics and Social Development, and Institute of Oceanography and Environment, Universiti Malaysia Terengganu, Malaysia. Email: marhana@umt.edu.my

Assoc. Prof. Dr. Khatijah Omar, Faculty of Business, Economics and Social Development, and Institute of Tropical Biodiversity \& Sustainable Development, Universiti Malaysia Terengganu, Malaysia. Email: khatijah@umt.edu.my

*Dr. Hayatul Safrah Salleh, Faculty of Business, Economics and Socia Development, and Institute of Oceanography and Environment, Universiti Malaysia Terengganu, Malaysia. Email: hayatul@umt.edu.my
Nur Khairunnisa Ahnual, Faculty of Business, Economics and Social

human waste and industrial waste, which has led to extensive pollution of the rivers, the impact of which has no simple solution [2].

The World Wide Fund (WWF) stated that polluted water not only impacts on humans, it also has adverse effects on plants and living organisms, as well as the economy in Malaysia [3]. Polluted water can endanger health and may cause serious illness, especially when microscopic organisms and bacteria are present in the polluted water. Illness caused by polluted water will affect people's health and well-being, especially for those who are not aware of the importance of clean water and for those who do not have adequate facilities to access clean water where they reside [4].

However, there are solutions to prevent water pollution becoming worse and to make it safe for human consumption, such as consuming clean water from a water filter. The innovative technology used in water filters provides clean and safe water that can be used directly as drinking water or for any kind of household activity with the assurance that there is no contaminant in the water. Apart from their convenience to use, the technology of water filters has contributed to the sustainable good health of the society. Thus, water filter products can be categorised as a sustainable product.

\section{PROBLEM STATEMENT}

Although Malaysia has plentiful water resources and receives ample rainfall, water scarcity and quality have become major problems in Malaysia. Water issues have been on national and international agendas due to water pollution for many years and such issues have been a significant problem for people worldwide. According to Haseena et al. [5], the major sources and contributors to water pollution are domestic sewage, industrialization, population growth, urbanization, pesticides and fertilizers, plastics and polythene bags, and weak management systems.

Water is the primary source for humans and other living things to survive. In addition, water is also used in many household, industrial, agriculture, and environmental activities [6]. Humans need clean water to survive and to be healthy. Thus, safe, clean and healthy drinking water is an important current issue because unclean water consumption can affect human health. Aini, Fakhru'l-Razi, Mumtazah, and Meow Chen [7], in their study on Malaysian households' drinking water practices, stated that the majority of the respondents $(70 \%)$ rated the quality 
of water that they received through their house as poor, $16 \%$ rated it as very poor, and only $15 \%$ were satisfied with the quality of the water they consumed.

Unhygienic and poor quality water can lead to infectious diseases, such as cholera, typhoid, and fever [8] as well as gastroenteritis, diarrhoea, vomiting, skin, and kidney problems [5]. Not only that, water pollution can also degrade the nutrition of plants and animals, which are the main sources of food for humans. These problems have led to the innovation of water filter systems. The function of basic water filters to remove odours, chlorine, turbidity, and microorganisms. However, some water filters incorporate advanced technology that can kill germs and bacteria. These innovations can provide clean and healthy water for society to consume as well as for household and domestic activities. Since water filter products can provide clean and healthy water to the consumers, which supports a healthy life, it is important to know the intention of Malaysian consumers towards the use of water filters in their daily life.

To date, empirical studies on profiling consumers' intention towards the use of healthy water consumption (water filters) in the Malaysian context are scarce. Thus, the purpose of this study is to examine the demographic profile of consumers' concerning their intention towards the use of water filters. The objectives of this study are, to determine the level of consumers' intention towards the use of water filters, and to examine the differences between the demographic factors towards intention to use water filters among Malaysian consumers.

\section{LITERATURE REVIEW}

Studies have found that health is deeply connected to the notion of sustainable products and is seen to be the strongest motive towards the use of water filters. A water filter can also be seen to provide water with a better taste, that is clean, and can kill microorganisms, and that is perceived to be a green product. The fact that consumers perceive water filters as environmentally-friendly is keenly connected to the value of universalism and is also said to be a dominant value when consumers buy sustainable products [9]. The intention is a concept that has been examined in the marketing literature. The concept of intention towards certain behaviour is linked to psychological traits and is widely used in behavioural studies [10]. It also acts as a behavioural tendency that may lead to an actual behaviour. Intention towards the behaviours, such as intention to use and to purchase can be influenced by the level of knowledge possessed by consumers [11]. In addition, intention can always change depending on consumers' perception towards perceived risk and price [12]. According to Klerck and Sweeney [13] knowledge about the product is a crucial factor that can influence both the perceived risk and intention. In this study, intention was operationalised as, the likelihood of an individual's motivation and willingness to use more of water filters. Bhattacherjee [14] suggested that this type of intention was also known as continuance intention, in other words behavioural intention to continue using water filters.

Demographics have been used by many studies to determine adoption behavior, and demographic factors may interact with consumer traits to determine consumers' intention to use green and healthy products [15]. Si Hassen et al. [16] and Royne, Levy, and Martinez [17], stated that social demographics have a huge impact on consumers' intention when choosing a green and healthy product. However, Urala [18] reported that not all consumers are ready to engage and have a willingness to use a green and healthy product. Magnusson, Avrola, Hursti Koivisto, Aberg, and Sjoden [19], stated that adult consumers have more intention to purchase environmentally-friendly products because they are more concerned about health and environmental care. In addition, Verbeke [20] and Santeramo, Devitiis, Carlucci, and Seccia [21] reported that healthy practices and healthy products are accepted through the presence of sick family members, information from doctors, and when there are children at home. Another study also shows that females have a high intention to use green and healthy products [22].

\section{RESEARCH METHODOLOGY}

A survey method was employed because this study keenly believes that survey research is the best method to obtain useful information. The method is widely used in social science fields, public opinion research, organizations, charities, as well as marketing research and journalism [23]. The unit of analysis for this study was individual consumers aged 18 and above because, at this age, they start to have their own financial dexterity, knowledge, and most contribute to the economy of Malaysia. Questionnaires were distributed online since most of the Malaysian population can be reached via an online survey without facing any geographical barriers.

The sampling procedure used for the present study was convenience sampling among Malaysian consumers. 240 questionnaires were collected. However, two respondents were excluded from the data set because they were aged below 18. A total of 238 responses were usable and used for subsequent analysis. The sample size was similar to other studies using consumers aged 18 and above, with respective sample sizes for such studies being 230 [24], [25]. Thus, the sample size for this study is found to be acceptable. The Statistical Package for the Social Sciences (SPSS) has been used to analysed the data. The analyses performed in order to answer the research objectives are descriptive statistics, independent t-test, and one-way ANOVA.

\section{RESULTS}

The result for Socio-demographic characteristics showed that $62.6 \%$ of the respondents were female and $37.4 \%$ were male. In total, $63.4 \%$ are aged $18-29,23.5 \%$ are aged $30-39$, $10.9 \%$ are aged $40-49$, and $2.1 \%$ are aged 50 and above. The majority of the respondents are single $(70.2 \%)$ and the minority are divorced $(2.1 \%)$. The majority of the respondents are Malay (74.4\%), $18.1 \%$ are Chinese and $7.5 \%$ are Indian. In terms of religion, the majority are Muslim (75.2\%), 14.3\% are Buddhist, $6.3 \%$ are Hindu, and $4.2 \%$ are Christian. In relation to the highest education, respondents with master/doctorate degree were $17.6 \%$, $52.5 \%$ graduated with a bachelor's degree, $19.7 \%$ with certificate/diploma, and $10.1 \%$ 
from secondary school. A monthly household income of RM 2000 and below is the most common among the respondents $(63.9 \%)$, and the lowest percentage of respondents are those that have an income of RM 6001-RM 9000 (2.1\%).

In this study, eight elements of water filter were listed for the respondents to state their level of general knowledge about water filters. As shown in Table I, clean water $(90.8 \%)$ was the highest element chosen by the respondents, followed by remove impurities, healthy drinks, non-toxic, remove bacteria, safe ingredients, kills germs, and prevents chronic diseases. Prevents chronic diseases was the least popular element of water filter chosen by the respondents, with only $36.1 \%$. This demonstrates that the respondents believe that water filters produce clean and safe water for consumption.

Table I: Knowledge and Opinion on Water Filters in General

\begin{tabular}{|l|c|}
\hline \multicolumn{1}{|c|}{ Element } & $\%$ \\
\hline Healthy drinks & 66.4 \\
Clean water & 90.8 \\
Removes impurities & 72.7 \\
Safe ingredients & 55.9 \\
Non-toxic & 60.5 \\
Prevents certain diseases & 36.1 \\
Kills Germs & 54.6 \\
Removes bacteria & 58.8 \\
\hline
\end{tabular}

Regarding the sources of information of water filter, the results in Table II show that most respondents obtained the information about water filters from electronic media, social networks, word of mouth, marketers, printed media, websites, and from doctors/nutritionists. However, the highest percentage showed that many respondents accessed electronic media (69.7\%), followed by $66.0 \%$ accessed social networks, $65.5 \%$ via word of mouth from friends and family, and $60.1 \%$ refer to marketers/promoters. The lowest source of information about a water filter is from doctors/nutritionists (19.3\%).

Table II: Sources of Information about Water Filters

\begin{tabular}{|l|c|}
\hline \multicolumn{1}{|c|}{ Element } & $\%$ \\
\hline Social network (Facebook, Twitter, email, Instagram) & 66.0 \\
Electronic media (advertisements on TV, radio, billboard) & 69.7 \\
Printed media (magazines, newspaper, product brochure) & 51.7 \\
Doctor, Nutritionist & 19.3 \\
Word of mouth (family, friends, relatives, neighbours) & 65.5 \\
Product's website & 38.2 \\
Marketer/Promoter & 60.1 \\
\hline
\end{tabular}

To simplify the interpretation for the descriptive statistic results, the five-point Likert scales were grouped into similarly sized categories of low, moderate and high. Therefore, scores of less than 2.33 [4/3+lowest value (1)] are considered as low; scores of 3.67 and above [highest value (5)-4/3] are considered high, and those in between are considered moderate [26]. Table III shows that the level of consumers' intention towards the use of water filters among Malaysian consumers is high $($ mean=4.24). The results explained that respondents believed that clean water is important for healthy life and the sustainability of human kind.

Table III: Descriptive analysis for Intention towards the use of Water Filters

\begin{tabular}{|c|c|c|}
\hline Variable & Mean & SD \\
\hline Intention & 4.24 & .70 \\
\hline
\end{tabular}

The differences across the demographic profiles of the respondents need to be investigated. Differences in the level of consumers' intention among gender can be analysed by using the independent t-test, as shown in Table IV. The result explains that the level of consumers' intention towards water filter usage among respondents is significantly different by gender $(\mathrm{F}=3.36 ; \mathrm{p}=.001)$.

Table IV: Consumers' Intention by Gender

\begin{tabular}{|l|c|c|c|c|}
\hline \multicolumn{1}{|c|}{$\begin{array}{c}\text { Independent } \\
\text { Variable }\end{array}$} & Mean & SD & F-Value & p-value \\
\hline Female & 4.35 & .62 & 3.36 & $.001^{*}$ \\
Male & 4.06 & .78 & & \\
\hline
\end{tabular}

Note: $* \mathrm{p}<0.05$

The differences in the level of consumers' intention in terms of age, marital status, ethnicity, religion, highest education, and monthly household income were analysed using analysis of variance (ANOVA). Table $\mathrm{V}$ enumerates the results of the analysis and shows that the level of consumers' intention to use water filters among the respondents did not vary by marital status $(\mathrm{F}=.81 ; \mathrm{p}=.45)$, ethnicity $(\mathrm{F}=.39 ; \mathrm{p}=.76)$, religion $(\mathrm{F}=.97 ; \mathrm{p}=.41)$ or education $(\mathrm{F}=2.05 ; \mathrm{p}=.11)$. However, the level of intention to use water filters was found to be different by age $(\mathrm{F}=2.83$; $\mathrm{p}=.03)$ and monthly household income $(\mathrm{F}=3.36 ; \mathrm{p}=.01)$.

Table V: Analysis of Variance (ANOVA)

\begin{tabular}{|l|c|}
\hline \multicolumn{1}{|c|}{ Independent Variable } & F-Value (p-value) \\
\hline Age & $2.83(.025)^{*}$ \\
Marital Status & $.81(.448)$ \\
Ethnicity & $.39(.762)$ \\
Religion & $.97(.409)$ \\
Education & $2.05(.108)$ \\
Income & $3.36(.011)^{*}$ \\
\hline \multicolumn{2}{|c}{ Note: ${ }^{*}<<0.05$}
\end{tabular}

\section{DISCUSSION}

This study demonstrated that the level of consumers' intention towards water filters among Malaysian consumers is high and encouraging. The majority of the respondents believed that filtered water is clean, healthy, and free from impurities. They also think that water filters are able to remove bacteria and kill germs, which leads and triggers the consumers to use a water filter for drinking and other domestic activities. This is in line with Zahid, Ahmad, Thurasamy, and Amin [27] who said that consumers' intention will increase once it comes to health terms, because it is the main factor in choosing green and healthy products. It is also supported by past studies that reported that consuming clean water can prevent infectious diseases, such as cholera, typhoid fever, [8] as well as gastroenteritis, diarrhoea, vomiting, skin, and kidney problems [5]. It shows that when people have a high level and positive attitude towards the need to consume clean and healthy water, that attitude will encourage their intention to use the water filter. This result is similar to Sutha and Thangadurai [28], who mentioned that consumers' attitude may convince their intention towards the use of water filter. The results are also supported by Teng, Rezai, Mohamed, and Shamsudin [29], 
and Salleh, Nik Mat, Mohd Noor, and Yusof [30], who stated that consumers in Malaysia have a positive intention towards green, sustainable and healthy products and are willing to pay for them. The conceivable reason explains that this finding is significantly positive towards consumer intention on water filter usage.

Majority of the respondents stated that the information about water filter products was learned from electronic media, social networks, and word of mouth. Thus, the results suggest that advertisements via electronic media and the internet should be applied by marketers in promoting their products.

Based on the demographic profile on healthy consumption, the findings in many cases produced mixed results and were not consistent with each other. In this study, the result explains that the consumers' intention towards water filter usage among the respondents is significantly different by gender. In which, females have a high intention to use water filters compared to males. This result was supported by Brough et al. [22], who reported that females have a high intention to use green and healthy products. This result is similar to Jezewska-zychowicz, Wadolowska, Kowalkowska, Lonnie, Czarnocinska and Babics- Zielinska [31], who stated that females are more willing to use a product that is enriched with minerals compared to males. This statement was also consistent with Hirschman [32], who mentioned that females were assumed to have the main role in household matters compared to their self-interests. This role leads their family to be concerned about their health and to protect them from harm. Thus, this concern may lead them to be more aware and begin to adapt their lifestyle to a healthy life, such as by consuming water from a water filter.

Age was found to be significantly different towards the intention to use a water filter. The result shows that older consumers aged 50 years and above have a higher level of intention to use water filters compared to consumers aged between 30 and 39 years old (middle adulthood). This finding may be due to the current trends of the healthy lifestyle in Malaysia [33] that encourage individuals to practice healthy eating for the health of their family. However, this result was in contrast with Rezai, Teng, Mohamed, and Shamsudin [34], who indicated that people in early adulthood (aged 18 to 29 years) are more aware and believe that green products are beneficial to their health. Meanwhile, the result showed that intention towards the use of water filters among respondents did not vary by marital status. This may be due to the responsibility held by all adults to emphasize the health of individuals as well as the family as a whole.

The present study also found that consumers' intention does not differ by ethnicity or religion. This result contrasts with Khare [35], who stated that choosing green products as their green practices, helps Indian consumers differentiate between non-environmental and environmental philosophy in choosing green products as their lifestyle. Another conceivable reason may be due to the accelerated economic development that has changed Malaysia's social synergy, lifestyle, and joint values. Malaysians will be triggered to disclose to other cultures and their structure due to the changes. A social synergy of different ethnic groups and religions will advocate perceptivity, esteem, and consent of green products among various cultures [36].

It is also found that the level of education is non-significantly associated with the consumers' intention in this study. This result was supported by Salleh et al. [30]. However, it is inconsistent with the studies of Kesse-Guyot et al. [37], Sangkumchaliang and Huang [38], and Ramesh and Divya [39], who reported that consumers who practice a healthy lifestyle are educated and have enough knowledge of green and healthy products. One plausible reason to explain this finding may be related to the knowledge possessed about water filters by consumers who know that clean water is able to remove impurities and bacteria and prevent certain illnesses. The diseases associated with unclean water may lead to high medical costs and involve expensive and sophisticated treatment as well as long-term care to recover. Thus, these issues have led to the willingness of consumers to spend more on water filter purchases for health benefits for themselves and their family.

In terms of household income, the result shows a significant difference towards the intention to use a water filter. The respondents with a higher income have a higher intention to use water filters compared to those with the lowest household income. The plausible reason to explain this finding is that those with a higher income can afford to buy green and healthy products, such as water filters, which are generally costly. This result is similar to Siro, Kapolna, Kapolna, and Lugasi [40], who indicated that consumers in the USA and Europe have a high intention to buy green and healthy products because of their knowledge and high monthly income.

\section{CONCLUSION}

This study aimed at investigating the consumers' demographic profile concerning their intention towards the use of water filters in the context of Malaysia. The analysis undertaken indicated that the level of consumers' intention towards the use of water filters among Malaysian consumers are high and encouraging. Respondents of different marital status, ethnicity, religion, and level of education were found to have similar thoughts concerning their intention to consume filtered water. Meanwhile, gender, age and monthly household income showed significant differences in their intention to use a water filter. The results also indicated that females, older consumers, and high-income families exhibited higher levels of consumer intention to use water filters.

The demographic profile from this study can provide some useful information for segmentation purposes. The marketers will be able to better understand the types of consumer that are more concern and responsive towards health issues and new technology of water filter. The marketers can use these results as a reference to improve on various marketing strategies, such as preferences for types of advertising and advertising tools, promotional appeals, and acceptance of new product technology that congruent with the demographic profile of the consumers, their preference and knowledge. This study also can give information to the society about the important to consume 
clean and healthy water from water filter technology for their good health and sustainable well-being.

Finally, this research was based on the response of consumers aged 18 and above and thus the result does not represent the Malaysian population in general. Other segments, such as teenagers and University students, who may have a different attitude and intention towards the use of water filters, should be investigated. Also, additional studies comparing the intention of consumers from different regions of Malaysia might produce interesting findings.

\section{REFERENCES}

1. Landrigan Landrigan, P. P. (2017). The Lancet Commission on pollution and health. New York: The Lancet Commissions.

2. Cosgrove, W. J. \& Loucks, D. P. (2015). Water management: Current and future challenges and research directions. Water Resour. Res., 51, 4823-4839.

3. Dhillon, R. (2015). A problem of water pollution in Malaysia becoming serious. Malaysia: The Rakyat Post.

4. Obasohan, E. E., Agbonlahor, D. E. \& Obano, E. E. (2010). Water pollution: A review of microbial quality and health concerns of water, sediment, and fish in the aquatic ecosystem. African Journal of Biotechnology, 9, 4, 423-427.

5. Haseena, M., Malik, M. F., Javed, A., Arshad, S., Asif, N., Zulfiqar, S. \& Hanif, J. (2017). Water Pollution and Human Health. Environmental Risk Assessment and Remediation, 1, 3 .

6. Rosegrant M. W., Cai X. \& Cline S. A. (2002). Global Water Outlook to 2025: Averting an impending crisis. USA: International Food Policy Research Institute Publication.

7. Aini, M. S., Fakhru'l-Razi, A., Mumtazah, O. \& Meow Chen, J. C. (2007) Malaysian households' drinking water practices: A case study. International Journal of Sustainable Development \& World Ecology, $14,5,503-510$.

8. Juneja, T. \& Chauhdary, A. (2013). Assessment of water quality and its effect on the health of residents of Jhunjhunu district, Rajasthan: A cross-sectional study. Journal of public health and epidemiology, 5, 4, $186-91$

9. Thøgersen, J. (2007). Consumer decision making with regard to organic food products, In Vaz, M.T.D.N., Vaz, P., Nijkamp, P. and Rastoin, J.L. (Eds), Transitional Food Production Facing Sustainability: A European Challenge, Farnham: Ashgate Publishing.

10. Dodd, M.D. \& Supa, D.W. (2011). Understanding the effect of corporate social responsibility on consumer purchase intention. Public Relations Journal, 5,3 .

11. Wang, Y. \& Hazen, B. (2016). Consumer product knowledge and intention to purchase remanufactured products. International Journal of Production Economics, 181, 460-469.

12. Zhang, Z. \& Hou, Y. (2017). The effect of perceived risk on information search for innovative products and services. J. Consum. Mark, 34, 241-254.

13. Klecrk, D. \& Sweeney, J. C. (2007). The Effect of Knowledge Types on Consumer- Perceived Risk and Adoption of Genetically Modified Foods. Psychology \& Marketing, 24, 2, 171-193.

14. Bhattacherjee, A. (2001). Understanding information systems continuance: An expectation confirmation model. MIS Quarterly, 25, 3, 351-370.

15. Paul, J. \& Rana, J. (2012). Consumer behavior and purchase intention for organic food. Journal of Consumer Marketing, 29, 6, 412-422.

16. Si Hassen, W., Castetbon, K., Péneau, S., Tichit, C., Nechba, A., Lampuré, A., . . Méjean, C. (2018). Socio-economic and demographic factors associated with snacking behavior in a large sample of French adults. International Journal of Behavioral Nutrition and Physical Activity, $15-25$.

17. Royne, M. B., Levy, M. \& Martinez, J. (2011). The Public Health Implications of Consumers' Environmental Concern and Their Willingness to Pay for an Eco-Friendly Product. The Journal of Consumer Affairs, 45, $2,329-343$.

18. Urala, N. (2005). Functional Foods in Finland: Consumers' views, attitudes and willingness to use. Espoo (2005). Finland: VTT Publications 581

19. Magnusson, M. K., Avrola, A., Hursti Koivisto, U. K., Aberg, L. \& Sjoden, P. O. (2001). Attitudes towards organic foods among Swedish consumers. British Food Journal, 103, 3, 209-226.

20. Verbeke, W. (2015). Profiling consumers who are ready to adopt insects as a meat substitute in Western society. Food Quality and Preference, 39, 147-155.
21. Santeramo, F., Devitiis, B., Carlucci, D. \& Seccia, A. (2017). Emerging trends in European food, diets, and food industry. Food Research International, 104, 39-47.

22. Brough, A. R., Wilkie, J. E., Ma, J., Isaac, M. S. \& Gal, D. (2016). Is Eco-Friendly Unmanly? The Green-Feminine Stereotype and Its Effect on Sustainable Consumption. Journal of Consumer Research, 43

23. Neuman, W. (2000). Sosial research methods: Qualitatives and quantitative approaches (4th ed). Boston: Allyn \& Bacon.

24. Bashir, A. M., Bayat, A., Olutuase, S. O., Ariff, Z. \& Latiff, A. (2018). Factors affecting consumers' intention towards purchasing halal food in South Africa: a structural equation modeling. Journal of Food Products Marketing. 25, 1, 26-48.

25. Sidi, H., Puteh Sharifah Ezat, W., Abdullah, N. \& Midin, M. (2007). The Prevalence of Sexual Dysfunction and Potential Risk Factors That May Impair Sexual Function in Malaysian Women. J Sex Med, 4, 311-321.

26. Azila, N., Mohd Noor, N., Muhammad, A., Kasim, A., Zuraini, C., Jamil, M., Mat, N., Mat, N. \& Salleh, H. S. (2012). Creating Green Consumers: How Environmental Knowledge and Environmental Attitude Lead to Green Purchase Behaviour?. International Journal of Arts and Sciences, 5 .

27. Zahid, M. M., Ali, B., Ahmad, M., S, Thurasamy, R. \& Amin, N. (2017) Factors Affecting Purchase Intention and Social Media Publicity of Green Products: The Mediating Role of Concern for Consequences. Corporate Social Responsibility and Environmental Management.

28. Sutha, A. \& Thangadurai, J. (2016). Consumer Attitude and Purchase Intention of Organic Food. International Journal of Marketing \& Financial Management, 4, 2, 22-30.

29. Teng, P., Rezai, G., Mohamed, Z. \& Shamsudin, M. (2012). Malaysian Consumers' Willingness-to-pay for Functional Food. 2nd International Conference on (ICM 2012). Kedah, Malaysia.

30. Salleh, H. S., Nik Mat, N. H., Mohd Noor, N., \& Yusof, Y. (2015). Consumer-Behavioural Intention Towards The Consumption Of Functional Food in Malaysia: Their Profiles and Behaviours. International Business \& Economics Research Journal, 14, 4.

31. Jezewska-Zychowic, M., Wadolowska, L., Kowalkowska, J., Lonnie, M., Czarnocinska, J. \& Babicz-Zielinska, E. (2017). Perceived Health and Nutrition Concerns as Predictors of Dietary Patterns among Polish Females aged 13-21 years (GEBaHealth Project). Nutrients, 9, 6.

32. Hirschman, C. (2017). Gender, the Status of Women, and Family Structure in Malaysia. Malaysian Journal of Economic Studies, 53, 1, 33-50.

33. Tee, J., Gan, W., Tan, K.-A., Chin, Y. (2018). Obesity and unhealthy lifestyle associated with poor executive function among Malaysian adolescents. PLOS ONE: Obesity, Lifestyle Behaviors, and Executive Function.

34. Rezai, G., Teng, P., Mohamed, Z. \& Shamsudin, M. (2012). Functional Food Knowledge and Perceptions among Young Consumers in Malaysia. International Journal of Economics and Management Sciences, 6 , 28-33.

35. Khare, A. (2015). Antecedents to green buying behavior: A study on consumers in an emerging economy. Marketing Intelligence \& Planning, $33,3,309-329$.

36. Hassan, S. (2011). Managing conflicting values in functional food consumption: the Malaysian Experience. British Food Journal, 113, 8, 1045-1059.

37. Kesse-Guyot, E., Peneau, S., Mejean, C., Edelenyi, F. S., Galan, P., Hercberg, S. \& Lairon, D. (2013). Profiles of Organic Food Consumers in Large Samples of French Adults: Results from the Nutrient-Sante Cohort Study. Consumers of Organic Products, 8, 10.

38. Sangkumchaliang, P. \& Huang, W. C. (2012). Consumers' perceptions and Attitudes of Organic Food Products in Northern Thailand. International Food and Agribusiness Management Review, 15, 1.

39. Ramesh, S. \& Divya, M. (2015). A study on consumers' awareness attitude and satisfaction towards select organic food products with reference to Coimbatore. International Journal of Interdisciplinary and Multidisciplinary Studies, 2, 4, 81-84.

40. Siro, I., Kapolna, E., Kapolna, B. \& Lugasi, A. (2008). Functional food Product development, marketing, and consumer acceptance-A review. Appetite, 5, 3, 456-467. 